\title{
Impact of Foliar Application of Boron and Zinc on Growth, Quality and Seed Yield of Okra
}

\author{
Md. Habibur Rahman ${ }^{1}$, Md. Abdul Quddus ${ }^{2, *}$, Md. Abdus Satter ${ }^{3}$, Md. Razzab Ali ${ }^{4}$, \\ Mohammad Hossain Sarker ${ }^{3}$, Tanjila Nasreen Trina ${ }^{5}$ \\ ${ }^{1}$ Regional Agricultural Research Station, Bangladesh Agricultural Research Institute, Cumilla, Bangladesh \\ ${ }^{2}$ Soil and Water Management Section, Horticulture Research Centre, Bangladesh Agricultural Research Institute, Gazipur, Bangladesh \\ ${ }^{3}$ Farm Division, Bangladesh Agricultural Research Institute, Gazipur, Bangladesh \\ ${ }^{4}$ Olericulture Division, Bangladesh Agricultural Research Institute, Gazipur, Bangladesh \\ ${ }^{5}$ Department of Genetics and Plant Breeding, Bangladesh Agricultural University, Mymensingh, Bangladesh
}

\section{Email address:}

rahmanag@yahoo.com (Md. H. Rahman), quddus06@yahoo.com (Md. A. Quddus), satter72@gmail.com (Md. A. Satter), razzab321@gmail.com (Md. R. Ali),hossain.agro@yahoo.com (Md. H. Sarker), trina.gpb@gmail.com (T. N. Trina)

${ }^{*}$ Corresponding author

\section{To cite this article:}

Md. Habibur Rahman, Md. Abdul Quddus, Md. Abdus Satter, Md. Razzab Ali, Mohammad Hossain Sarker, Tanjila Nasreen Trina. Impact of Foliar Application of Boron and Zinc on Growth, Quality and Seed Yield of Okra. Journal of Energy and Natural Resources. Special Issue: Assessment of Potassium Element on Lentil (Lens culinaris Medic) Agronomy and Nutrient Use Efficiency in Calcareous Soils. Vol. 9, No. 1, 2020, pp. 1-9. doi: 10.11648/j.jenr.20200901.11

Received: January 12, 2020; Accepted: February 4, 2020; Published: February 13, 2020

\begin{abstract}
The experiment was carried out in the field of Horticulture Research Centre (HRC), Bangladesh Agricultural Research Institute (BARI), Gazipur to evaluate the effect of foliar application of boron (B) and zinc (Zn) on growth, yield attributes, quality and seed yield of okra. The experiment was planned with 16 treatment combinations comprising four levels each of $\mathrm{B}(0,0.1,0.2$ and $0.3 \%$ borax, respectively) and $\mathrm{Zn}(0,0.1,0.2$ and $0.3 \%$ zinc sulphate, respectively) along with the blanket dose of fertilizers of N, P, K, S and cow dung at 120, 40, 80, 20 and $10000 \mathrm{~kg} \mathrm{ha}^{-1}$, respectively were used in all treatments. The two factor experiment was laid out in the randomized complete block design with three replications. Results revealed that the foliar application of boron and zinc either single or in combination had significant effect on yield, yield attributes and quality of okra seed. Most of the yield attributes of okra were significantly increased by the combined foliar application of borax and zinc sulphate up to $0.2 \%$ borax and $0.2 \%$ zinc sulphate. The highest seed yield $\left(2.52 \mathrm{t} \mathrm{ha}^{-1}\right)$ was obtained from the treatment combination of $0.2 \%$ borax and $0.2 \%$ zinc sulphate followed by the treatment combination of $0.2 \%$ borax and $0.3 \%$ zinc sulphate. The highest oil content (16\%) in seed was also produced from the same treatment $(0.2 \%$ borax and $0.2 \%$ zinc sulphate). The improved protein content (17.75\%) was found in combination of $0.1 \%$ borax and $0.3 \%$ zinc sulphate. The combined foliar applications of zinc and boron fertilizers were detected superior to their single application. The results suggest that the combination of $0.2 \%$ borax and $0.2 \%$ zinc sulphate could be used as foliar for seed yield maximization of okra. Hence, the foliar fertilization rates of zinc sulphate should be increased for okra production.
\end{abstract}

Keywords: Boron and Zinc, Quality, Yield Attribute, Okra Seed Yield

\section{Introduction}

Okra (Abelmoschus esculentus L.) is a nutritious summer vegetable in Bangladesh. One of the main constraints of okra production is lack of quality seed. Quality seed is the key requirement of successful crop production. By using quality seed, production can be increased up to $15-50 \%[1,2]$. In
Bangladesh, the estimated annual requirement of okra seed is about 300-400 tones [3, 4]. Observation denoted that Bangladesh Agricultural Development Corporation (BADC) and private seed companies produced about $25 \%$ of the total okra seed; another $25 \%$ seeds are imported. The rest $50 \%$ seeds are farmer's own produced seeds. The farmer's preserved seeds are, in most cases, of inferior quality and 
used of these poor quality seeds are responsible for low yield in Bangladesh [5]. Several factors like genetically purity; balanced fertilization including micro nutrient, preventive measure the pest and disease infestation and appropriate cultural management contributed to achieve higher yield of good quality seed. Micronutrients such as boron and zinc both are played significant role for producing good quality vegetable seed. Foliar application of micronutrient to the crops is a good option which immediate fulfills the specific nutrient deficiency. A number of studies have highlighted the benefits of foliar fertilization in improving plant growth, crop yield, nutrient uptake and product quality $[6,7,8]$. Foliar application is the best way to nourish plants that grow in soil with poor quality due to adverse $\mathrm{pH}$ [9]. The zinc and boron deficiency in soils of Bangladesh is most prevalent [10]. Boron and zinc influences directly or indirectly for improving the yield and quality seed production of okra [11]. Boron is required for proper development and differentiation of plant tissues [12]. The absence of boron abnormal formation and development of fruit occur. Since boron is relatively immobile in plants, the early casualties of boron deficiency occur in the reproductive process of plants, in addition to male sterility, pistil sterility is happened due to boron deficiency $[13,14]$. Boron facilitates the transport of carbohydrates through cell membranes. It is involved in flowering and fruiting of the plant. Boron deficiency affects the growing points of roots and youngest leaves $[15,16]$. Maximum production of starch and sugar is restricted if crops are suffered inadequate supply of boron [17]. Zinc mainly functions as the metal component of a series of enzymes, chlorophyll synthesis and cell membrane integrity. The most important enzymes activated by this element are carbonic anhydrase and a number of dehydrogenases [18]. Zinc deficiency is thought to restrict RNA synthesis, which in turn inhibits protein synthysis [19]. Zinc is also involved in auxin production and flower and fruit setting [20]. Zinc application also helps in increasing the uptake of nitrogen and potash. Zinc provides a protective mechanism against the excessive uptake of boron. Zinc is necessary for root cell membrane integrity, and its function, it prevents excessive $\mathrm{P}$ uptake by roots and transport of $\mathrm{P}$ from roots to leaves [21]. Information about the effects of boron and zinc in soil applications are available but the foliar application of boron and zinc on growth, quality and seed yield of okra is inadequate in Bangladesh. Hence, the study was undertaken to find out the effective foliar spray dose of boron and zinc on growth, quality and seed yield maximization of okra.

\section{Materials and Methods}

\subsection{Experimental Site and Soil}

The experiment was conducted during April 2013 to September 2013 at the field of Horticulture Research Centre (HRC), Bangladesh Agricultural Research Institute (BARI), located in the moist monsoon subtropical region of Gazipur $\left(24^{\circ} 0^{\prime} 13^{\prime \prime} \mathrm{N}\right.$ latitude; $90^{\circ} 25^{\prime} 0^{\prime \prime} \mathrm{E}$ longitude) at an elevation of $8.4 \mathrm{~m}$ above sea level. The soils in this area are classified as grey terrace according to the USDA Soil Taxonomy [22] and belong to the chhiata soil series under the agroecological zone - Madhupur Tract (AEZ-28). The experimental site has a typical tropical and sub-tropical continental monsoon climatic condition. It is characterized by comparatively high monsoon rainfall, high humidity, and high temperature [23]. The mean annual air temperature is $31.9^{\circ} \mathrm{C}$. The mean annual precipitation is $451.8 \mathrm{~mm}$, with approximately $72.9 \%$ occurring from June to October.

Before starting the experiment, initial soil sample (0-15 $\mathrm{cm})$ of the experiment was analyzed and the chemical properties are presented in the Table 1.

Table 1. Initial nutrient status of the experimental soil.

\begin{tabular}{|c|c|c|c|c|c|c|c|c|c|c|}
\hline \multirow{2}{*}{ Location } & \multirow{2}{*}{$\mathbf{p H}$} & \multirow{2}{*}{ ОМ\% } & $\mathrm{Ca}$ & Mg & $\mathbf{K}$ & \multirow{2}{*}{ Total N\% } & $\mathbf{P}$ & $\mathbf{S}$ & $\mathbf{Z n}$ & B \\
\hline & & & meq $100 \mathrm{~g}$ & & & & \multicolumn{4}{|l|}{$\mu \mathrm{g} \mathrm{g}^{-1}$} \\
\hline Gazipur & 6.6 & 1.20 & 6.0 & 2.3 & 0.13 & 0.064 & 13.4 & 13.1 & 0.73 & 0.17 \\
\hline Critical level & - & - & 2.0 & 0.50 & 0.12 & 0.12 & 7.0 & 10 & 0.6 & 0.2 \\
\hline Interpretation* & Slightly acidic & Low & Optimum & Very high & Low & Very low & Medium & Medium & Low & Low \\
\hline
\end{tabular}

*Fertilizer Recommendation Guide, [18]

\subsection{Land Preparation, Treatments, Design and Layout}

A tractor operated disc plough was used for open the land. After that the land was prepared thoroughly by tractor operated rotavetor followed by laddering and leveling. The experiment was planned with 16 treatment combinations comprising four levels each of B $(0,0.1,0.2$ and $0.3 \%$ borax, respectively) and $\mathrm{Zn}(0,0.1,0.2$ and $0.3 \%$ zinc sulphate, respectively) along with the blanket dose of fertilizer of $\mathrm{N}, \mathrm{P}$, $\mathrm{K}, \mathrm{S}$ and cow dung at 120, 40,80, 20 and $10000 \mathrm{~kg} \mathrm{ha}^{-1}$, respectively was used in all treatments. The treatments were arranged viz. $\mathrm{T}_{1}=\mathrm{B}_{0} \mathrm{Zn}_{0} ; \mathrm{T}_{2}=\mathrm{B}_{0} \mathrm{Zn}_{0.1} ; \mathrm{T}_{3}=\mathrm{B}_{0} \mathrm{Zn}_{0.2} ; \mathrm{T}_{4}=\mathrm{B}_{0} \mathrm{Zn}_{0.3}$; $\mathrm{T}_{5}=\mathrm{B}_{0.1} \mathrm{Zn}_{0} ; \quad \mathrm{T}_{6}=\mathrm{B}_{0.1} \mathrm{Zn}_{0.1} ; \quad \mathrm{T}_{7}=\mathrm{B}_{0.1} \mathrm{Zn}_{0.2} ; \quad \mathrm{T}_{8}=\mathrm{B}_{0.1} \mathrm{Zn}_{0.3}$;
$\mathrm{T}_{9}=\mathrm{B}_{0.2} \mathrm{Zn}_{0} ; \quad \mathrm{T}_{10}=\mathrm{B}_{0.2} \mathrm{Zn}_{0.1} ; \quad \mathrm{T}_{11}=\mathrm{B}_{0.2} \mathrm{Zn}_{0.2} ; \quad \mathrm{T}_{12}=\mathrm{B}_{0.2} \mathrm{Zn}_{0.3} ;$ $\mathrm{T}_{13}=\mathrm{B}_{0.3} \mathrm{Zn}_{0} ; \quad \mathrm{T}_{14}=\mathrm{B}_{0.3} \mathrm{Zn}_{0.1} ; \quad \mathrm{T}_{15}=\mathrm{B}_{0.3} \mathrm{Zn}_{0.2}$ and $\mathrm{T}_{16}=\mathrm{B}_{0.3} \mathrm{Zn}_{0.3}$. The spray treatments were clarified as $\mathrm{B}_{0}=0 \%$ borax (as $0 \%$ boron), $\mathrm{B}_{0.1}=0.1 \%$ borax (as $0.01 \%$ boron), $\mathrm{B}_{0.2}=0.2 \%$ borax (as $0.02 \%$ boron), $\mathrm{B}_{0.3}=0.3 \%$ borax (as $0.03 \%$ boron) and $\mathrm{Zn}_{0}$ $=0 \%$ zinc sulphate (as $0 \%$ zinc), $\mathrm{Zn}_{0.1}=0.1 \%$ zinc sulphate (as $0.04 \%$ zinc), $\mathrm{Zn}_{0.2}=0.2 \%$ zinc sulphate (as $0.07 \%$ zinc), $\mathrm{Zn}_{0.3}=$ $0.3 \%$ zinc sulphate (as $0.11 \%$ zinc). The two factor experiment was laid out in the randomized complete block design with three replications. The sources of N, P, K, S, B and Zn were urea, TSP, MoP, gypsum, boric acid and zinc sulphate, respectively. The unit plot size was $4 \mathrm{~m} \times 2.4 \mathrm{~m}$, where 40 
plants were accommodated in each plot at a spacing of $60 \mathrm{~cm}$ $\times 40 \mathrm{~cm}$. Two adjacent unit plots were separated by $70 \mathrm{~cm}$ space, and there was $100 \mathrm{~cm}$ space between the blocks.

\subsection{Preparation of $B$ and Zn Spray Solution and Application Method}

As per the treatment details one gram of borax was dissolved in one litre water in a container to make 0.1 per cent borax solution and one gram of zinc sulphate was dissolved in one litre of water in another container to make the concentration of 0.1 per cent zinc sulphate solution. Similarly two grams and three grams of borax and zinc sulphate were dissolved in one litre of water to make $0.2 \%$ and $0.3 \%$ borox and zinc sulphate solution, respectively. Then all the micronutrient solutions were used to spray. The foliar spray was given for three times first before flowering at 32 DAS, second after third picking, at 85 DAS and third one at 15 days after second spray. On the other hand, full dose of cowdung, TSP, gypsum, $1 / 2$ of MoP and $1 / 4$ of urea were applied during final land preparation. Remaining MoP was applied at 40 days after sowing. Rest of urea was applied with 3 equal splits at 20,40 and 60 days after sowing.

\subsection{Seed Sowing and Agronomic Practice}

The test crop variety was BARI Dharosh-1. Healthy seeds were sown in a line maintaining plant to plant distance of 40 $\mathrm{cm}$ and three seeds were sown per pit. After 12 days of sowing (5-6 leaves stage), comparatively weak seedlings were removed from each pit and finally only one healthy and vigorous seedling was kept in a pit. Two hand weedings were done for all plots at 25 and 60 days after sowing. The disease influx was managed by spraying the fungicide Secure $600 \mathrm{wg}$ (a) $0.2 \%$ two times at an interval of 10 days start at flowering stage. The insect (pod borer and aphid) infestations were controlled by spraying Karate @ 0.2\% two times at 10 day intervals start at fruit bearing stage. Irrigation was applied as and when required. Seeds were collected after picking the mature fruits.

\subsection{Data Collection Procedure}

\subsubsection{Seed Collection}

Seeds were collected manually from the fruits and cleaned, graded and sun dried for 4 days to attain the acceptable moisture level as close to $8 \%$ measured by Seed Buro moisture meter (12 Series Moisture Tester, Model-1200).

\subsubsection{Plant Height}

The height of the plant was measured with a meter scale taking 10 plants randomly selected from a treatment plot when harvesting of fruits was completed. Average height was determined adding the total length of all the 10 plants and dividing by ten.

\subsubsection{Number of Fruits Per Plant}

The number of fruit per plant was recorded by counting all fruits harvested from ten plants randomly selected in each treatment plot and was divided by ten.

\subsubsection{Length of Fruit}

The length of fruit was determined by measuring the vertical length of the fruit by using a $30 \mathrm{~cm}$ (12 inch) ruler. Average length of fruit was determined by adding the total length of the fruit divided by the total number of fruits harvested separately from ten plants which selected randomly in each treatment.

\subsubsection{Girth of Fruit}

The girth of fruit was determined by measuring the width of the same fruit by using a digital slide calipers. Average girth of fruit was determined by sum of the total diameter of fruits divided by the total number of fruits harvested separately from ten plants which selected randomly in each treatment.

\subsubsection{Thousand Seed Weight}

Thousand seed weight $(\mathrm{g})$ was determined by the counting of 500 seeds randomly from each plot and was weighing through electronic balance and converting it into 1000-seed weight.

\subsubsection{Seed Yield per Hectare}

The seed yield per plot was recorded, and then per plot yield was converted into $\mathrm{tha}^{-1}$.

\subsubsection{Protein Content in Seed}

Protein content of seeds was estimated following the method described by Lowery et al. [24]. One gram of each seed sample was soaked in distilled water for 4 hours and then crushed. After crushing, distilled water was added up to a volume of $100 \mathrm{ml}$. Then filtrate was defatted by adding diethyl ether. Then $0.4 \mathrm{ml}$ of the supernatant was pipetted in a test tube containing freshly prepared Folin-Ciocalteau Phenol reagent. The mixture of these three solutions was then shaken and allowed to stand for 30 minute. The optical density was measured in a spectrophotometer at $750 \mathrm{~nm}$. Bovin Serum albumin was used to plot a standard curve for estimation of protein content in the solution. Each sample was replicated three times. Samples have been preserved for next analysis. Protein content was determined quarterly.

\subsubsection{Oil Content in Seed}

The oil percentage was estimated following Gadgil et al. [25] method from moisture-free seed meal by solvent extraction using other petroleum ether (boiling point $60^{\circ} \mathrm{C}$ to $80^{\circ} \mathrm{C}$ ) in a Soxhlet appratus for eight hours. The meal was pre-dried $\left(60^{\circ} \mathrm{C} ; 24\right.$ hours). Two grams of meal were used for the estimation of oil. No further oil was recovered from the residue after eight hour of refluxing.

\subsection{Soil Sample Collection and Analysis}

Initial soil sample (0-15 cm depth) of three locations were collected and brought to the laboratory and spread on a brown paper for air drying. The air-dried soil samples were ground and passed through a $2-\mathrm{mm}$ sieve. The sieving soil samples were kept into plastic container with proper label for chemical analysis. Soil pH was measured by glass electrode 
pH meter using soil: water ratio of 1: 2.5 [26]. Organic carbon was determined following the wet oxidation method as described by Page et al. [26] and the organic matter content was calculated by multiplying the $\%$ organic carbon with the Van Bemmelen factor 1.73. Total $\mathrm{N}$ by Microkjeldahl method [27]; available $\mathrm{P}$ was determined following Bray and Kurtz [28] method; exchangeable $\mathrm{K}$ by $1 \mathrm{~N} \mathrm{NH} \mathrm{NH}_{4} \mathrm{OAc}$ method [29]; exchangeable $\mathrm{Ca}$ by $1 \mathrm{~N} \mathrm{NH}_{4} \mathrm{OAc}$ method [30]; available $\mathrm{S}$ by turbidity method using $\mathrm{BaCl}_{2}$ [31]; available $\mathrm{Zn}$ by DTPA method [32]; available B by azomethine-H method [26].

\subsection{Statistical Analysis}

Collected data were analyzed statistically using MSTAT-C computer package program. The significance of the difference among the treatments was estimated by Duncan's Multiple Range Test (DMRT) at 5\% level of probability [33].

\section{Results}

\subsection{Main Effect of Boron}

Insignificant variation was observed in the plant height due to foliar application of boron (Table 2). It was observed that the plant height was gradually increased with the increasing levels of borax application. Results reveal that the highest plant height $(159.37 \mathrm{~cm})$ was recorded with $0.3 \%$ borax application where as it was the lowest $(155.91 \mathrm{~cm})$ from control. Number of fruits per plant is very important yield attribute which significantly correlated to achieve higher seed yield of okra. However, the number of fruits per plant was affected significantly by different rates of boron containing fertilizer. This study result showed that the highest number of fruit per plant (18.51) was observed with the level of B $(0.2 \%$ borax), which was statistically identical with $0.3 \%$ borax and it was the lowest (17.27) with no borax application. The fruit length of okra showed significantly difference due to foliar application of boron. The highest fruit length $(16.83 \mathrm{~cm})$ was recorded from plants treated with $0.2 \%$ borax which was statistically similar with $16.72 \mathrm{~cm}$ from $0.3 \%$ borax, while it was the lowest $(15.65 \mathrm{~cm})$ when no borax was applied (Table 2 ). There was no significant variation among the treatments in fruit girth of okra due to foliar application of borax (Table 2). From the study, fruit girth was ranged from $1.72 \mathrm{~cm}$ to $1.79 \mathrm{~cm}$ among the borax rates. Maximum fruit girth $(1.79$ $\mathrm{cm})$ was recorded with $0.2 \%$ borax followed by $(1.77 \mathrm{~cm})$ with $0.3 \%$ borax, while minimum $(1.72 \mathrm{~cm})$ was found from control treatment. The number of filled seeds per fruit was significantly influenced by different levels of borax application. From the study number of seeds per fruit was varied from 55.96 to 58.83 among the levels of borax, and the highest number of filled seeds per fruit (58.83) was obtained from $0.2 \%$ borax, which was statistically comparable with $0.3 \%$ borax (58.79) while minimum (55.96) was recorded with no application of borax (Table 2).

Table 2. Main effect of boron as foliar application on growth and yield attributes of okra.

\begin{tabular}{|c|c|c|c|c|c|}
\hline Treatments & Plant height (cm) & No. of fruits plant ${ }^{-1}$ & Fruit length (cm) & Fruit girth $(\mathrm{cm})$ & No. of seeds fruit ${ }^{-1}$ \\
\hline $\mathrm{B}_{0}$ & 155.91 & $17.27 \mathrm{c}$ & $15.65 \mathrm{c}$ & 1.72 & $55.96 \mathrm{~b}$ \\
\hline $\mathrm{B}_{0.1}$ & 157.68 & $17.85 b$ & $15.98 \mathrm{~b}$ & 1.75 & $57.17 \mathrm{ab}$ \\
\hline $\mathrm{B}_{0.2}$ & 159.34 & $18.51 \mathrm{a}$ & $16.83 \mathrm{a}$ & 1.79 & $58.83 \mathrm{a}$ \\
\hline $\mathrm{B}_{0.3}$ & 159.37 & $18.40 \mathrm{a}$ & $16.72 \mathrm{a}$ & 1.77 & $58.79 \mathrm{a}$ \\
\hline Level of significance & NS & $*$ & $* *$ & NS & $* *$ \\
\hline $\mathrm{CV}(\%)$ & - & 2.25 & 3.62 & - & 2.23 \\
\hline
\end{tabular}

Note: $\mathrm{B}_{0}=0 \%$ borax (as $0 \%$ boron), $\mathrm{B}_{0.1}=0.1 \%$ borax (as $0.01 \%$ boron), $\mathrm{B}_{0.2}=0.2 \%$ borax (as $0.02 \%$ boron), $\mathrm{B}_{0.3}=0.3 \%$ borax (as $0.03 \%$ boron)

The seed weight was also significantly correlated to reflect the higher yield of okra. Marked variation in 1000-seed weight was found due to foliar application of B containing fertilizer. The highest 1000 -seed weight $(59.27 \mathrm{~g})$ was observed from $0.3 \%$ borax and the lowest (56.04 g) was recorded from no application of borax (Table 3). Protein content of seeds was differed significantly due to $\mathrm{B}$ application. It was increased with increasing level of borax up to $0.2 \%$ and then decreased (Table 3). The highest $(17.66 \%)$ content of protein was found in $0.2 \%$ borax application, which was statistically identical with $0.3 \%$ borax $(17.64 \%)$ and the lowest $(16.78 \%)$ was in control. Slight variation was observed among the treatments in respect of oil content of seeds due to borax application, but it was showed insignificant. It is increased with increasing the level of borax. The highest oil content (15.91\%) was observed with $0.3 \%$ borax followed by $0.2 \%$ borax $(15.90 \%)$, whereas the lowest $(15.14 \%)$ was noted with no borax application (Table 3 ). The seed yield of okra responded significantly to the application of different levels of borax. The experiment results reveal that the highest yield of seed $\left(2.39 \mathrm{t} \mathrm{ha}^{-1}\right)$ was obtained from $0.2 \%$ borax which was statistically similar with $0.3 \%$ borax $\left(2.37 \mathrm{tha}^{-1}\right)$ and the lowest $\left(2.00 \mathrm{t} \mathrm{ha}^{-1}\right)$ was from no borax application (Table 3 ).

Table 3. Main effect of boron as foliar application on seed yield and quality attributes of okra.

\begin{tabular}{llll}
\hline Treatment & $\mathbf{1 0 0 0}$-seed wt. (g.) & Protein content in seed (\%) Oil content in seed (\%) $^{\left.\text {Seed yield (t ha }^{-1}\right)}$ \\
\hline $\mathrm{B}_{0}$ & $56.04 \mathrm{c}$ & $16.78 \mathrm{~b}$ & 15.14 \\
$\mathrm{~B}_{0.1}$ & $57.45 \mathrm{~b}$ & $17.43 \mathrm{a}$ & 15.59 \\
$\mathrm{~B}_{0.2}$ & $59.21 \mathrm{a}$ & $17.66 \mathrm{a}$ & 15.90 \\
$\mathrm{~B}_{0.3}$ & $59.27 \mathrm{a}$ & $17.64 \mathrm{a}$ & 15.91 \\
Level of significance & $*$ & $* *$ & $\mathrm{NS}$ \\
\hline
\end{tabular}




\begin{tabular}{lllll}
\hline Treatment & $\mathbf{1 0 0 0}$-seed wt. (g.) & Protein content in seed (\%) & Oil content in seed (\%) & Seed yield $\left(\mathrm{t} \mathrm{ha}^{-1}\right)$ \\
\hline $\mathrm{CV}(\%)$ & 0.65 & 1.74 & - & 2.28 \\
\hline
\end{tabular}

Note: $\mathrm{B}_{0}=0 \%$ borax (as $0 \%$ boron), $\mathrm{B}_{0.1}=0.1 \%$ borax (as $0.01 \%$ boron), $\mathrm{B}_{0.2}=0.2 \%$ borax (as $0.02 \%$ boron), $\mathrm{B}_{0.3}=0.3 \%$ borax (as $0.03 \%$ boron)

\subsection{Main Effect of Zinc}

Plant height was increased due to use of $\mathrm{Zn}$ containing fertilizer; however it was non-significant (Table 4). It was recorded highest $(158.68 \mathrm{~cm})$ in $0.3 \%$ zinc sulphate application and lowest $(157.07 \mathrm{~cm})$ in control. Significant variation was observed in respect of number of fruit per plant due to the foliar application of zinc sulphate. Number of fruit per plant was the maximum (18.39) in $0.3 \%$ zinc sulphate, while the lowest in (17.33) in control (Table 4). Regarding length of okra fruit, it was showed similar trend of number of fruit per plant. This study showed that it was ranged from 16.04 to $16.45 \mathrm{~cm}$ across the treatments; fruit per plant was the highest $(16.45 \mathrm{~cm})$ with $0.3 \%$ zinc sulphate and $0.2 \%$ zinc sulphate $(16.44 \mathrm{~cm})$ application both was statistically similar and the control having the lowest $(16.04 \mathrm{~cm})$. Fruit girth was increased with increasing level of zinc sulphate application (Table 4) up to $0.2 \%$ and then decreased. The okra plant got with $0.2 \%$ zinc sulphate by foliar application was produced the highest fruit girth $(1.79 \mathrm{~cm})$, while the lowest $(1.73 \mathrm{~cm})$ was found from no application of zinc sulphate. The number of filled seeds per fruit was increased with the increasing levels of zinc sulphate application up to $0.3 \%$ (Table 4 ). The highest number of filled seeds per fruit (58.69) was recorded from $0.3 \%$ zinc sulphate, which was statistically similar with $0.2 \%$ zinc sulphate (58.55), whereas the lowest (56.17) was recorded with no zinc sulphate application (Table 4).

Table 4. Main effect of foliar application of zinc on growth and yield attributes of okra.

\begin{tabular}{llllll}
\hline Treatments & Plant height $(\mathbf{c m})$ & No. of fruits plant & Fruit length $(\mathbf{c m})^{\mathbf{1}}$ & Fruit Girth (cm) $^{\text {No. of seeds fruit }^{-1}}$ \\
\hline $\mathrm{Zn}_{0}$ & 157.07 & $17.33 \mathrm{~b}$ & $16.04 \mathrm{c}$ & 1.73 & $56.17 \mathrm{~b}$ \\
$\mathrm{Zn}_{0.1}$ & 157.91 & $18.00 \mathrm{a}$ & $16.26 \mathrm{~b}$ & 1.76 & $57.33 \mathrm{ab}$ \\
$\mathrm{Zn}_{0.2}$ & 158.62 & $18.32 \mathrm{a}$ & $16.44 \mathrm{a}$ & 1.79 & $58.55 \mathrm{a}$ \\
$\mathrm{Zn}_{0.3}$ & 158.68 & $18.39 \mathrm{a}$ & $16.45 \mathrm{a}$ & 1.75 & $58.69 \mathrm{a}$ \\
Level of significance & $\mathrm{NS}$ & $*$ & $* *$ & $\mathrm{NS}$ & $*$ \\
$\mathrm{CV}(\%)$ & - & 2.25 & 3.62 & - & 2.23 \\
\hline
\end{tabular}

Note: $\mathrm{Zn}_{0}=0 \%$ zinc sulphate (as $0 \%$ zinc), $\mathrm{Zn}_{0.1}=0.1 \%$ zinc sulphate (as $0.04 \%$ zinc), $\mathrm{Zn}_{0.2}=0.2 \%$ zinc sulphate (as $0.07 \%$ zinc), $\mathrm{Zn}_{0.3}=0.3 \%$ zinc sulphate (as $0.11 \%$ zinc)

Thousand seed weight was ranged from $57.17 \mathrm{~g}$ to $58.47 \mathrm{~g}$ across to different zinc sulphate rates of foliar application, while the highest 1000 seed weight $(58.38 \mathrm{~g})$ was recorded from $0.2 \%$ zinc sulphate which was statistically similar with $0.3 \%$ zinc sulphate $(58.47 \mathrm{~g})$ and the lowest $(57.17 \mathrm{~g})$ was recorded from the control plot (Table 5). The effect of zinc sulphate application had also significant effect on protein content of seed (Table 5). The foliar application of $0.3 \%$ zinc sulphate showed significantly superiority to increase protein content $(17.50 \%)$ in seeds and control treatment showed the lowest protein content (17.14\%) in seed. Foliar application of zinc sulphate had no significant effect on oil content in seed of okra. It was the highest $(15.75 \%)$ in $0.2 \%$ zinc sulphate application and the lowest $(15.45 \%)$ was in control. In case of seed yield, significantly maximum seed yield $2.33 \mathrm{t} \mathrm{ha}^{-1}$ was recorded under foliar application of $0.3 \%$ zinc sulphate which was statistically at par the treatment receiving of $0.2 \%$ and $0.1 \%$ zinc sulphate, respectively. The lowest seed yield $2.05 \mathrm{t} \mathrm{ha}^{-1}$ was recorded from the control treatment (Table 5).

Table 5. Main effect of foliar application of zinc on yield contributing and quality characters of okra seed.

\begin{tabular}{llcll}
\hline Treatments & 1000-seed wt. (g.) & Protein content in seed (\%) & Oil content in seed (\%) & Seed yield (t ha $\left.\mathbf{~}^{-1}\right)$ \\
\hline $\mathrm{Zn}_{0}$ & $57.17 \mathrm{~b}$ & $17.14 \mathrm{~b}$ & 15.45 & $2.05 \mathrm{~b}$ \\
$\mathrm{Zn}_{0.1}$ & $57.94 \mathrm{a}$ & $17.38 \mathrm{ab}$ & 15.62 & $2.21 \mathrm{a}$ \\
$\mathrm{Zn}_{0.2}$ & $58.38 \mathrm{a}$ & $17.49 \mathrm{a}$ & 15.75 & $2.32 \mathrm{a}$ \\
$\mathrm{Zn} 0.3$ & $17.50 \mathrm{a}$ & 15.74 & $2.33 \mathrm{a}$ \\
Level of significance & $58.47 \mathrm{a}$ & $* *$ & $\mathrm{NS}$ & $* *$ \\
$\mathrm{CV}(\%)$ & $*$ & 1.74 & - & 2.28 \\
\hline
\end{tabular}

Note: $\mathrm{Zn}_{0}=0 \%$ zinc sulphate (as $0 \%$ zinc), $\mathrm{Zn}_{0.1}=0.1 \%$ zinc sulphate (as $0.04 \%$ zinc), $\mathrm{Zn}_{0.2}=0.2 \%$ zinc sulphate (as $0.07 \%$ zinc), $\mathrm{Zn}_{0.3}=0.3 \%$ zinc sulphate (as $0.11 \%$ zinc)

A polynomial relationship was observed between seed yield and application rates of borax. The seed yield trend of okra was increased significantly positive between the applications of $0.2 \%$ to $0.3 \%$ borax to the okra plant, but the trend of seed yield was showed statistically similar between the borax rates of $0.2 \%$ to $0.3 \%$ (Figure 1). A polynomial relationship was also detected in between seed yield of okra and foliar application rates of zinc sulphate. The trend of okra seed yield was exhibited highly positive but statistically similar between applications of $0.2 \%$ to $0.3 \%$ zinc sulphate (Figure 2). Therefore, the optimum dose of zinc containing fertilizer will be estimated after the rearrange the rates of zinc sulphate in future study. 


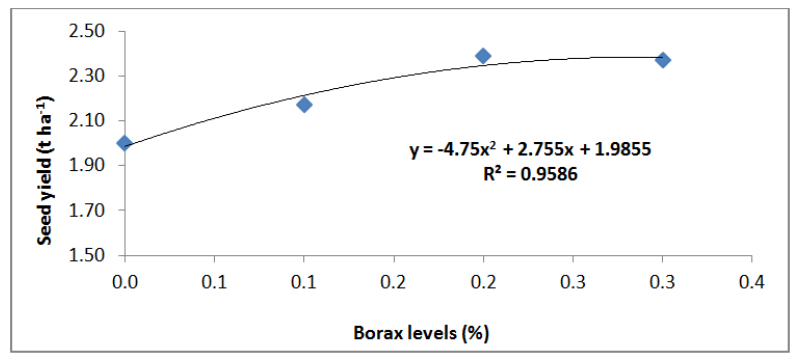

Figure 1. Relationship between borax application and seed yield of okra.

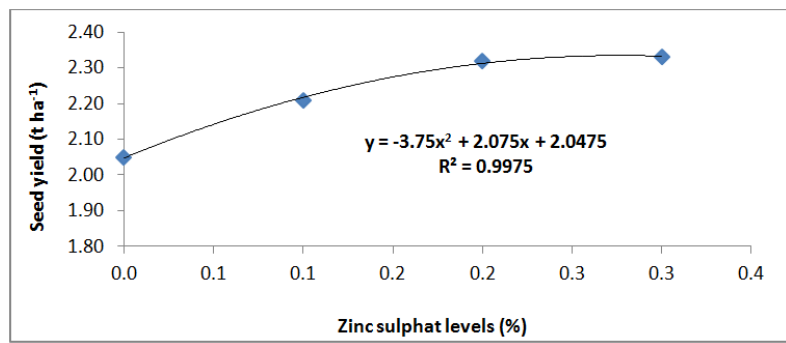

Figure 2. Relationship between zinc sulphat application and seed yield of okra.

\subsection{Interaction Effect of Boron and Zinc}

The interactions between boron with zinc were not noticed significant in increasing in plant height of okra. The tallest plant $(160.00 \mathrm{~cm})$ was recorded from the treatments of $\mathrm{T}_{11}$ and $\mathrm{T}_{12}$, while the dwarf plant $(155.31 \mathrm{~cm})$ was found in control $\left(\mathrm{T}_{1}\right)$ treatment (Table 6). The interaction effect of boron and zinc was significant on number of fruits per plant. Significantly the highest number of fruits per plant (19.00) was recorded from $\mathrm{T}_{11}=\mathrm{B}_{0.2} \mathrm{Zn}_{0.2}$ treatment which was statistically identical to $\mathrm{T}_{12}, \mathrm{~T}_{14}, \mathrm{~T}_{15}, \mathrm{~T}_{16}, \mathrm{~T}_{10}, \mathrm{~T}_{8}$ and $\mathrm{T}_{7}$ treatments and the lowest number of fruit per plant (17.05) was found in control $\left(\mathrm{T}_{1}\right)$ treatment (Table 6). Length of fruit was also influenced by combined application of boron and zinc. Results reveal that maximum fruit length $(17.00 \mathrm{~cm})$ was found in the treatments of $T_{11}, T_{12}$ and $T_{15}$ those were significantly different with the other treatment but statistically identical to $\mathrm{T}_{14}$ and $\mathrm{T}_{10}$ treatments and the minimum fruit length $(15.55 \mathrm{~cm})$ was found in control $\left(\mathrm{T}_{1}\right)$ treatment. The interactions between boron and zinc did not influenced significantly on the fruit girth of okra. From the study, the fruit girth ranged from $1.71 \mathrm{~cm}$ to $1.82 \mathrm{~cm}$ across the treatments. The highest fruit girth was $(1.82 \mathrm{~cm})$ found in $\mathrm{T}_{11}$ treatment, while the lowest $(1.71 \mathrm{~cm}$ ) in control (Table 6). Results obtained on filled seed per fruit varied significantly due to application of both boron and zinc. Significantly the highest number of filled seeds per fruit (59.86) was noted from $\mathrm{T}_{11}$ (combination of $0.2 \%$ borax and $0.2 \%$ zinc sulphate) which was statistically similar to most of the cases and the lowest (55.00) from no borax and zinc sulphate application (Table 6).

Table 6. Interaction effect of foliar application of boron and zinc on growth and yield attributes of okra.

\begin{tabular}{|c|c|c|c|c|c|}
\hline Treatments & Plant height (cm) & No. of fruits plant ${ }^{-1}$ & Fruit length $(\mathrm{cm})$ & Fruit girth $(\mathrm{cm})$ & No. of seeds fruit ${ }^{-1}$ \\
\hline $\mathrm{T}_{1}=\mathrm{B}_{0} \mathrm{Zn}_{0}$ & 155.31 & $17.05 \mathrm{~d}$ & $15.55 \mathrm{~d}$ & 1.71 & $55.00 \mathrm{c}$ \\
\hline $\mathrm{T}_{2}=\mathrm{B}_{0} \mathrm{Zn}_{0.1}$ & 155.38 & $17.31 d$ & $15.60 \mathrm{~d}$ & 1.71 & $55.30 \mathrm{bc}$ \\
\hline $\mathrm{T}_{3}=\mathrm{B}_{0} \mathrm{Zn}_{0.2}$ & 156.50 & $17.43 \mathrm{~cd}$ & $15.75 \mathrm{~d}$ & 1.75 & $56.78 \mathrm{abc}$ \\
\hline $\mathrm{T}_{4}=\mathrm{B}_{0} \mathrm{Zn}_{0.3}$ & 156.45 & $17.31 \mathrm{~d}$ & $15.70 \mathrm{~d}$ & 1.70 & $56.75 \mathrm{abc}$ \\
\hline $\mathrm{T}_{5}=\mathrm{B}_{0.1} \mathrm{Zn}_{0}$ & 156.40 & $17.30 \mathrm{~d}$ & $15.70 \mathrm{~d}$ & 1.67 & $55.70 b c$ \\
\hline $\mathrm{T}_{6}=\mathrm{B}_{0.1} \mathrm{Zn}_{0.1}$ & 157.66 & $17.60 \mathrm{bcd}$ & $15.70 \mathrm{~d}$ & 1.75 & $56.50 \mathrm{abc}$ \\
\hline $\mathrm{T}_{7}=\mathrm{B}_{0.1} \mathrm{Zn}_{0.2}$ & 158.00 & $18.00 \mathrm{a}-\mathrm{d}$ & $16.00 \mathrm{c}$ & 1.78 & $57.80 \mathrm{abc}$ \\
\hline $\mathrm{T}_{9}=\mathrm{B}_{0.2} \mathrm{Zn}_{0}$ & 158.60 & $17.50 \mathrm{bcd}$ & $16.45 \mathrm{~b}$ & 1.78 & $57.00 \mathrm{abc}$ \\
\hline $\mathrm{T}_{10}=\mathrm{B}_{0.2} \mathrm{Zn}_{0.1}$ & 158.75 & $18.58 \mathrm{ab}$ & $16.87 \mathrm{a}$ & 1.78 & $58.88 \mathrm{ab}$ \\
\hline $\mathrm{T}_{11}=\mathrm{B}_{0.2} \mathrm{Zn}_{0.2}$ & 160.00 & $19.00 \mathrm{a}$ & $17.00 \mathrm{a}$ & 1.82 & $59.86 \mathrm{a}$ \\
\hline $\mathrm{T}_{12}=\mathrm{B}_{0.2} \mathrm{Zn}_{0.3}$ & 160.00 & $18.95 \mathrm{a}$ & $17.00 \mathrm{a}$ & 1.79 & $59.57 \mathrm{a}$ \\
\hline $\mathrm{T}_{13}=\mathrm{B}_{0.3} \mathrm{Zn}_{0}$ & 158.00 & $17.45 \mathrm{~cd}$ & $16.45 b$ & 1.74 & $57.00 \mathrm{abc}$ \\
\hline $\mathrm{T}_{14}=\mathrm{B}_{0.3} \mathrm{Zn}_{0.1}$ & 159.85 & $18.50 \mathrm{abc}$ & $16.85 \mathrm{a}$ & 1.79 & $58.65 \mathrm{abc}$ \\
\hline $\mathrm{T}_{15}=\mathrm{B}_{0.3} \mathrm{Zn}_{0.2}$ & 159.97 & $18.84 \mathrm{a}$ & $17.00 \mathrm{a}$ & 1.80 & $59.76 \mathrm{a}$ \\
\hline Level of significance & NS & $*$ & $* *$ & NS & $*$ \\
\hline $\mathrm{CV}(\%)$ & - & 2.25 & 3.62 & - & 2.23 \\
\hline
\end{tabular}

Note: $\mathrm{B}_{0}=0 \%$ borax (as $0 \%$ boron), $\mathrm{B}_{0.1}=0.1 \%$ borax (as $0.01 \%$ boron), $\mathrm{B}_{0.2}=0.2 \%$ borax (as $0.02 \%$ boron), $\mathrm{B}_{0.3}=0.3 \%$ borax (as $0.03 \%$ boron)

$\mathrm{Zn}_{0}=0 \%$ zinc sulphate (as $0 \%$ zinc), $\mathrm{Zn}_{0.1}=0.1 \%$ zinc sulphate (as $0.04 \%$ zinc), $\mathrm{Zn}_{0.2}=0.2 \%$ zinc sulphate (as $0.07 \%$ zinc), $\mathrm{Zn}$. $0.11 \%$ zinc)

The thousand seed weight and protein content in seed was responded significantly to foliar applications of different doses of borax and zinc sulphate (Table 7). The results indicated that the highest 1000 -seed weight $(59.98 \mathrm{~g})$ was noted from the plants produced in $\mathrm{T}_{11}$ treatment which was statistically as same as $\mathrm{T}_{10}, \mathrm{~T}_{12}, \mathrm{~T}_{14}, \mathrm{~T}_{15}$ and $\mathrm{T}_{16}$ treatments and the lowest $(55.55 \mathrm{~g}$ ) was recorded from control (no borax and zinc sulphate application) treatment. The highest protein content $(17.75 \%)$ produced in seed with $\mathrm{T}_{8}$ (combination of
$0.1 \%$ borax and $0.3 \%$ zinc sulphate) treatment, which was statistically alike to $\mathrm{T}_{11}, \mathrm{~T}_{12}, \mathrm{~T}_{13}, \mathrm{~T}_{14}, \mathrm{~T}_{15}, \mathrm{~T}_{16}, \mathrm{~T}_{10}, \mathrm{~T}_{9}, \mathrm{~T}_{7}$ and $\mathrm{T}_{6}$ treatments and the lowest $(16.52 \%)$ was produced in seeds with no borax and zinc sulphate application (Table 7). No significant difference was found in oil content of seeds among the treatment combination of borax and zinc sulphate (Table 7). The highest oil content $(16.00 \%)$ in seed was produced in $\mathrm{T}_{11}$ (combination between $0.2 \%$ borax and $0.2 \%$ zinc sulphate) and the lowest oil content $(15.00 \%)$ was noted 
in the seeds in control $\left(\mathrm{T}_{1}\right)$ treatment. The interaction between boron and zinc also had the positive effect on the yield of seed per hectare. The yield per hectare was increased with the increasing levels of borax and zinc sulphate up to $0.2 \%$ borax and $0.2 \%$ zinc sulphate and then decreased. This was found to be maximum $\left(2.52 \mathrm{t} \mathrm{ha}^{-1}\right)$ in $\mathrm{T}_{11}$ treatment (combination of $0.2 \%$ borax and $0.2 \%$ zinc sulphate) and the lowest seed yield (1.93 tha $\left.{ }^{-1}\right)$ was recorded from no application of borax and zinc sulphate (Table 7).

Table 7. Interaction effect of foliar application of boron and zinc on yield contributing characters and quality of okra seed.

\begin{tabular}{|c|c|c|c|c|}
\hline Treatments & 1000-Seed wt. (g.) & Protein content in Seed $(\%)$ & Oil content in Seed (\%) & Seed yield (tha-1.) \\
\hline $\mathrm{T}_{1}=\mathrm{B}_{0} \mathrm{Zn}_{0}$ & $55.55 \mathrm{e}$ & $16.52 \mathrm{~d}$ & 15.00 & $1.93 \mathrm{f}$ \\
\hline $\mathrm{T}_{2}=\mathrm{B}_{0} \mathrm{Zn}_{0.1}$ & $55.90 \mathrm{e}$ & $16.70 \mathrm{~d}$ & 15.10 & $1.97 \mathrm{ef}$ \\
\hline $\mathrm{T}_{3}=\mathrm{B}_{0} \mathrm{Zn}_{0.2}$ & 56.40de & $16.97 \mathrm{bcd}$ & 15.25 & $2.06 \mathrm{def}$ \\
\hline $\mathrm{T}_{4}=\mathrm{B}_{0} \mathrm{Zn}_{0.3}$ & $56.31 \mathrm{de}$ & $16.95 \mathrm{bcd}$ & 15.23 & $2.04 \mathrm{def}$ \\
\hline $\mathrm{T}_{5}=\mathrm{B}_{0.1} \mathrm{Zn}_{0}$ & $56.25 \mathrm{de}$ & $16.90 \mathrm{~cd}$ & 15.20 & $2.00 \mathrm{ef}$ \\
\hline $\mathrm{T}_{6}=\mathrm{B}_{0.1} \mathrm{Zn}_{0.1}$ & $57.51 \mathrm{~cd}$ & $17.48 \mathrm{abc}$ & 15.58 & $2.11 \mathrm{def}$ \\
\hline $\mathrm{T}_{7}=\mathrm{B}_{0.1} \mathrm{Zn}_{0.2}$ & $57.55 \mathrm{~cd}$ & $17.60 \mathrm{abc}$ & 15.77 & $2.21 \mathrm{bcd}$ \\
\hline $\mathrm{T}_{9}=\mathrm{B}_{0.2} \mathrm{Zn}_{0}$ & $58.50 \mathrm{bc}$ & $17.60 \mathrm{abc}$ & 15.80 & $2.16 \mathrm{cde}$ \\
\hline $\mathrm{T}_{10}=\mathrm{B}_{0.2} \mathrm{Zn}_{0.1}$ & $58.85 \mathrm{abc}$ & $17.64 \mathrm{abc}$ & 15.85 & $2.38 \mathrm{ab}$ \\
\hline $\mathrm{T}_{11}=\mathrm{B}_{0.2} \mathrm{Zn}_{0.2}$ & $59.98 \mathrm{a}$ & $17.70 \mathrm{ab}$ & 16.00 & $2.52 \mathrm{a}$ \\
\hline $\mathrm{T}_{12}=\mathrm{B}_{0.2} \mathrm{Zn}_{0.3}$ & $59.50 \mathrm{ab}$ & $17.68 \mathrm{ab}$ & 15.97 & $2.48 \mathrm{a}$ \\
\hline $\mathrm{T}_{13}=\mathrm{B}_{0.3} \mathrm{Zn}_{0}$ & $58.38 \mathrm{bc}$ & $17.56 \mathrm{abc}$ & 15.78 & $2.14 \mathrm{de}$ \\
\hline $\mathrm{T}_{14}=\mathrm{B}_{0.3} \mathrm{Zn}_{0.1}$ & $59.50 \mathrm{ab}$ & $17.69 \mathrm{ab}$ & 15.96 & $2.38 \mathrm{ab}$ \\
\hline $\mathrm{T}_{15}=\mathrm{B}_{0.3} \mathrm{Zn}_{0.2}$ & $59.60 \mathrm{ab}$ & $17.70 \mathrm{ab}$ & 15.98 & $2.48 \mathrm{a}$ \\
\hline Level of significance & $*$ & $* *$ & NS & * \\
\hline $\mathrm{CV}(\%)$ & 0.65 & 1.74 & - & 2.28 \\
\hline
\end{tabular}

Note: $\mathrm{B}_{0}=0 \%$ borax (as $0 \%$ boron), $\mathrm{B}_{0.1}=0.1 \%$ borax (as $0.01 \%$ boron), $\mathrm{B}_{0.2}=0.2 \%$ borax (as $0.02 \%$ boron), $\mathrm{B}_{0.3}=0.3 \%$ borax (as $0.03 \%$ boron)

$\mathrm{Zn}_{0}=0 \%$ zinc sulphate (as $0 \%$ zinc), $\mathrm{Zn}_{0.1}=0.1 \%$ zinc sulphate (as $0.04 \%$ zinc), $\mathrm{Zn}_{0.2}=0.2 \%$ zinc sulphate (as $0.07 \% \mathrm{zinc}$ ), $\mathrm{Zn_{0.3 }}=0.3 \% \mathrm{zinc}$ sulphate (as $0.11 \%$ zinc)

\section{Discussion}

Plant height of the okra did not significantly influenced by boron. On the other hand, foliar application of zinc has significant effect on plant height. Similar result was observed by Abbasi et al. [34], who reported that foliar application of zinc produced good results for plant height and branching of okra. Sharangi et al. [35] reported that spraying of $0.2 \% \mathrm{Zn}$ on fennel lead to increase of plant height. The present study demonstrated that the interaction effect of boron and zinc significantly influenced to fruit set of okra. The maximum number of fruit plant ${ }^{-1}$ was recorded from the plants receiving as foliar of $0.2 \%$ borax and $0.2 \%$ zinc sulphate. Combined of Boron and zinc application might be helped balanced absorption of nutrients, increasing the rate of photosynthesis, as a result fruit per plant was highest. These results are supported to the findings of Mahesh et al. [36] who were investigated the interaction effect of boron and zinc on okra that might be helped to better pollen germination and growth of pollen tube and more number of fruit set. Boron facilitates the reduction of male sterility and increase normal fruit. Zinc involved in the biochemical synthesis of phytohormone, IAA through the pathway of conversion of tryptophan to IAA, which also improved yield and its attributes. The results are also supported to the report of Al-Dulaimi et al. [37] and AlUbaydi et al. [38], where they obtained a significant increase in the pod number, pod weight and total yield when applying zinc as foliar application in bean plants. Zinc influences the flower fertilization, pollen production and number of flower which ultimately affected on the production of fruit. The foliar application of boron, zinc and their interaction was significantly effect on fruit length of okra. Muhammad et al. [39] reported that higher level of boron and zinc application was increased the fruit length. Different rates of boron, zinc and their combinations were contributed significantly to improve the number of seeds in fruit of okra. The experimental results showed that the highest number of filled seeds fruit $^{-1}$ was obtained due to combined application of $0.2 \%$ borax and $0.2 \%$ zinc sulphate followed by $0.2 \%$ borax and $0.3 \%$ zinc sulphate to the okra plant. Shruti and Chauhan, [40] reported that the application of zinc, boron and manganese lead to increase the number of seed of okra fruit. Wen et al. [41] noted that the application of boron increased the number of seeds $\operatorname{pod}^{-1}$ by $41-52 \%$ in alfalfa crop. Significant variation was observed in 1000-seed weight due to foliar application of boron and zinc. It was found that 1000 -seed weight was linearly increased with application of both the micronutrients individually or their combination over control treatments. Sharangi et al. [35] conducted an experiment on fennel and showed that foliar application of $0.1 \% \mathrm{~B}$ resulted in the highest seeds umbel $^{-1}$ and 1000 seed weight. Boron is important for development and growth of new cells in the plant meristem and it plays a pivotal role in pollination, fruit set and seeds formation, movement of nitrogen, phosphorus, starches, etc in different crops [42]. The increase in seed weight might be due to better mineral utilization of plants accompanied with enhancement of photosynthesis, other metabolic activity and greater diversion of food material to seed [43]. In the present experiment born, zinc and their interaction was created influenced significantly 
to the protein content in seed. These two micronutrients might be due to facilitate in more protein synthesis. However the improved protein content was found in combined application of $0.1 \%$ borax and $0.3 \%$ zinc sulphate followed by $0.2 \%$ borax and $0.3 \%$ zinc sulphate. Similar phenomenon noted by Zaver and Vaghani Manji, [44] who observed that spraying of zinc significantly contributed to get improved protein in seeds of okra. These results are agreed by Alrawi and Aljumail [45], who reported that spraying of zinc significantly affects the protein of okra seeds. In this experiment, the highest seed yield per hectare was obtained from the single application of $0.2 \%$ borax, while the maximum seed yield was found in the alone foliar spraying of $0.3 \%$ zinc sulphate. The interaction between the $0.2 \%$ borax and $0.2 \%$ zinc sulphate was contributed to achieve the highest seed yield of okra. Wen et al. [41] conducted an experiment on alfalfa who observed that the application of boron increased seed yield by $22-35 \%$. Zeidan et al. [46] also reported that application of $\mathrm{Zn}, \mathrm{Fe}$ and $\mathrm{Mn}$ significantly increased grain yield of wheat. Increase in seed yield might be correlated to increase in number of fruit per plant and seed weight. This result is supported by Kumar and Sen [47] who reported that the interaction effect of zinc and boron significantly influenced on the seed yield of okra. The above results and discussion indicated that both the boron and zinc were involved in many physiological activities, photosynthesis, and respiration and nitrogen metabolism and synergistic affects to uptake the other nutrients by plant.

\section{Conclusion}

It could be concluded that foliar application of boron and zinc either single or in combinations, resulted improved seed yield, good performance of yield contributing characters and quality of okra seeds. The treatment $\mathrm{T}_{11}$ (combination of $0.2 \%$ borax and $0.2 \%$ zinc sulphate) demonstrated the highest results in respect to seed yield and most of the yield attributes of okra. The combined foliar applications of boron and zinc fertilizers were detected superior to their single application. The results suggest that the combination of $0.2 \%$ borax and $0.2 \%$ zinc sulphate could be used as foliar for seed yield maximization of okra. Hence, the foliar fertilization rates of zinc sulphate should be increased for okra production.

\section{References}

[1] George, R. A. T. (1985). Vegetable Seed Production. John Willy and Sons, 605, Third Avenue, New York. pp. 318.

[2] Kanwar, H. S. (2017). Advances in quality seed production of vegetable crops. Training manual, Centre of advanced faculty training in horticulture (vegetables), Department of vegetable science, YSP University of Horticulture and Forestry Nauni 173230 Solan, Himachal Pradesh, India

[3] BBS, (2018). Yearbook of Agricultural Statistics of Bangladesh-2017. Bangladesh Bureau of statistics. Statistics and informatics Division. Ministry of planning. Government of the people's republic of Bangladesh.

[4] AIS. (2008). Krishi Diary. Agricultural Information Service, DAE, Ministry of Agriculture, Government of the Peoples Republic of Bangladesh, Dhaka.

[5] Mew, T. W. 1997. Seed health testing: Progress towards $21^{\text {st }}$ Century. In: Huthins and Ruces (Editors), Development of rice seed health testing policy. pp. 129-138.

[6] Abbasi, F. F, Baloch M. A, Leghari, M. H, Oad F. C, Buriro R. A. (2010). Effect of commercial foliar fertilizers. Indus $J$ Pl Sci. 4 (4): 495-501.

[7] El-Aal, F. S. A., Shaheen A. M., Ahmed A. A. and Mahmoud A. R. (2010). Effect of foliar application of urea and amino acids mixtures as antioxidants on growth, yield and characteristics of squash. Research Journal of Agriculture and Biological Sciences, 6: 583-588.

[8] Zodape, S. T., Gupta A., Bhandari S. C., Rawat U. S., Chaudhry D. R., Eswaran K. and Chikara J. (2011). Foliar application of seaweed sap as biostimulant for enhancement of yield and quality of tomato (Lycopersicon esculentum Mill.). Journal of Scientific and Industrial Research, 70: 215-219.

[9] Ishii, T., Matsunaga, T., Iwai, H., Satoh, S., Taoshita, J. (2002). Germanium dose not substitute for boron in crosslinking of rhamnogalacturonan II in pumpkin cell walls. Plant Physiol. 130 (4): 1967-1973.

[10] Jahiruddin, M. (2015). Zinc and boron deficiency in crops and their management in Bangladesh. Department of Soil Science, Bangladesh Agricultural University, Mymensingh, pp 1-27.

[11] Rahman M. H, Hossain, I, Ahmad, M. U. Rahim, M. A. (2017). Effects of boron and zinc on yield and quality of okra seed, Advances in Bioresearch. 8 (1): 202-211 DOI: 10.15515/abr.0976-4585.8.1.202211.

[12] Jeanine M. Davis, Douglas C. Sanders, Paul V. Nelson, Laura Lengnick, and Wade J. Sperry (2003). Boron Improves Growth, Yield, Quality, and Nutrient Content of Tomato. $J$. Amer. Soc. Hort. Sci., 128 (3): 441-446.

[13] Singh, A. K., Khan, M. A., and Srivastava, A. (2014). Effect of boron and molybdenum application on seed yield of mungbean. Asian Journal of Biolological Science, 9, 169-172.

[14] Agarwala, S. C., Sharma, P. N., Chatterjee, C., Sharma, C. P. (1981). Development and enzymatic change during pollen development in boron deficiency maize plants. Journal of Plant Nutrition. 3. 329-336.

[15] Sultana, S., Niaz A., Ahmed Z. A., Anwer S. A., Anjum M. A., Ilyas M. (2017). Effect of boron application on growth, yield and quality of bitter gourd. Science Letters 2017; 5 (1): $1-7$.

[16] Sharma, C. P. (2006). Plant Micronutrients. Science Publishers, Enfield, USA; 265.

[17] Kalloo, 1985. Tomato. Allied Publishers, New Delhi, India. pp. 204-211.

[18] Fertilizer Recommendation Guide, (2012). Fertilizer Recommendation Guide. Bangladesh Agricultural Research Council, Farmgate, Dhaka, Bangladesh.

[19] Katyal, J. C. and N. S. Randhawa. (1983). Micronutrients. FAO Fertilizer and Plant Nutrition Bulletin. 3-76. 
[20] Ali, A., Ahmad, B., Hussain, I., Ali, A.\&Ali Shah, F. (2017). Effect of phosphorus and zinc on yield of lentil. Pure and Applied Biology, 6 (4), 1397-1402.

[21] Welch, R. M, Webb, M. J, Lonegaran, J. F. (1982). Zinc in membrane function and its role in phosphorus toxicity. In: Proceedings of the Ninth International Plant Nutrition Colloquium. Commonwealth Agricultural Bureau, A Scarify (Editor), Farnham Royal, England. pp. 710-715.

[22] USDA Soil Survey Staff. (1975). Soil taxonomy: a basic system of soil classification for making and interpreting soil surveys. USDA Agric. Handb. 436. U. S. Government Printing Office, Washington, D. C. $754 \mathrm{p}$

[23] Huq, S. M. I. and Shoaib J. U. M. (2013). The Soils of Bangladesh, World Soils Book Series 1, Springer Science.

[24] Lowery, O. H, Rosenbrough, N. R. J, Far, A. L, Randil, R. J. (1951). Protein measurement with the folin phenol reagent. Journal of Biological Chemistry. 193: 265-275.

[25] Gadgil, J. D., K. N. Susseelan, R. Mitra, D. C. Joshua, C. R. Bhatia. (1989). Chemical composition of seed and electrophoretic pattern of seed storage protein of jute Corchorus olitorius and Corchorus capsularius. Seed Sci. Technol. 17: 499-506.

[26] Page, A. L., Miller R. H. and Keeney D. R. (Eds.). (1982). Agronomy Series 9 ASA, SSSA. Methods of Soil Analysis (Part 2, 2nd ed., pp. 403-427). American Society of Agronomy, Madison, USA.

[27] Bremner, J. M. and Mulvaney, C. S. (1982). Total nitrogen. In A. L. Page, R. H. Miller, D. R. Keeney (Eds.), Methods of Soil Analysis (Part 2, 2nd ed., pp. 599-622). American Society of Agronomy, Madison, USA.

[28] Bray R. H. and Kurtz L. T. (1945). Determination of total, organic and available forms of phosphorus in soils. Ibid. 59: $39-45$.

[29] Jackson, M. L. (1973). Soil Chemical Analysis (p. 498). Prentice Hall of India Private Limited, New Delhi.

[30] Gupta, P. K. (2004). Soil, Plant, Water and Fertilizer Analysis. Department of Agricultural Chemistry and Soil Science, Maharana Pratap University of Agriculture \& Technology, Rajasthan, India, Pp 168-170

[31] Fox, R. L.; Olsen, R. A.; Rhoades, H. F. (1964). Evaluating the sulphur status of soil by plant and soil test. Soil Science Society of America Proc., 28, 243-246.

[32] Lindsay, W. L. and Norvell, W. A. (1978). Development of DTPA soil test for zinc, iron, manganese and copper. Soil science Society of American Journal, 42: 421-8.

[33] Gomez, K. A., and A. A., Gomez, (1984). Statistical procedure for agricultural research (2nd ed.). International Rice Research Institute. Willey Intl. Sci, Singapore. pp. 28192.

[34] Abbasi, F. F., Baloch M. A., Zia-ul-hassan Wagan K. H., Shah A. N., Rajpar I. (2010). Growth and yield of okra under foliar application of some new multinutrient fertilizer products.
Pakistan Journal of Agriculture, Agricultural Engineering and Veterinary Sciences, 26 (2): 11-18.

[35] Sharangi, A. B, Pariari, A, Chatterjee, R, Das, D. K. (2002). Response of boron and zinc on growth and seed yield of fennel. Journal of Interacademicia, 6 (4): 472-475.

[36] Mahesh, K, Sen, N. L. 2004. Interaction effect of zinc and boron on okra (Abelmoschus esculentus L. Moench) cv. Prabhani Kranti. Agric. Sci. Digest. 24 (4): 307-308.

[37] Al- dulaimi, A. H. T. and M. A. Al-jumaili. (2017). Role of iron, zinc and organic nutrient on yield of green beans. The Iraqi Journal of Agricultural Sciences. 48 (3): 462-471.

[38] Al-Ubaydi, A. A. Z. (2006) Response of Bean (Phaseolus Vulgaris L.) to Different Levels from Foam Sulfur and Zn, Mn Foliar Sprays, M.Sc. Thesis, Department of Horticulture and Landscape Gardening, Agriculture College, Baghdad University. pp: 88

[39] Muhammad, A. B, Abdul, Q. G, Muhammad, I. J, Tariq, A, Sher, A, Mohammad, I. M, Muhammad, S, Javed, A. A, Syed, I. A. S. (2019). Response of okra verities, to zinc and boron supplement under the agro-climatic condition of TandojamPakistan. Pure and Applied Biology. 8 (1): 601-608. http://dx.doi.org/10.19045/bspab.2018.700222

[40] Shruti, B. and Chauhan, S. V. S. (2001). Effect of zinc boron and manganese on yield in okra (Abelmoschus esculentus). Indian journal of Agricultural Sciences. 71 (5): 332-333.

[41] Wen, H. D, Xin, H. T, Zhi, Z. C, Alan, H. (2009). Effects of Micronutrients on Seed Yield and Yield Components of Alfalfa. Journal of Plant Nutrition, 32 (5): 809-820. DOI: $10.1080 / 01904160902787909$

[42] Lewis, D. H. 1980. Boron lignifications and the origin of vascular plants - a united hypothesis. New Phytol. 84: 209229.

[43] Naga, S. K., Swain, S. K., Sandeep, V. V., Raju, B. (2013). Effect of foliar application of micronutrients on growth parameters on tomato (Lycopersicon esculentum Mill). $J$. Agric. Food Sci. 1: 146-151.

[44] Zaver, Vaghani Manji. (2007), Effect of Gibberellic Acid, Zinc and Iron on Seed Production of Okra [Abelmoschus esculentus (L.) Moench]. Ph.D. Dissertcetion in Horticulture, Junagadh Agricultural University, College of Agriculture, Department of Horticulture. pp: 189

[45] Alrawi, M. M. A. and Aljumail M. A. H. (2018). Effect of foliar application with potassium and zinc on growth, pod yield and seed production of okra. Iraqi Journal of Agricultural Sciences, 49 (6): 1041-1048.

[46] Zeidan, M. S., Mohamed, M. F., Hamouda, H. A. (2010). Effect of foliar fertilization of $\mathrm{Fe}, \mathrm{Mn}$ and $\mathrm{Zn}$ on wheat yield and quality in low sandy soils fertility. World J. Agric. Sci. 6: 696-699.

[47] Kumar, M. and Sen N. L. (2004). Interaction effect of zinc and boron on okra (Abelmoschus esculentus L. moench) cv. prabhani kranti. Agnc. Sci. Digest, 24 (4): 307-308. 